\title{
HYDROGEOLOGICAL ASSESSMENT OF THE SALINIZATION PROBLEM OF XILAGANI - IMEROS AQUIFER SYSTEM IN SW PLAIN AREA OF RHODOPE PREFECTURE, GREECE
}

\author{
Pliakas F. ${ }^{1}$, Mouzaliotis A. ${ }^{1}$, Kallioras A. ${ }^{1}$, and Diamantis I. $^{1}$ \\ ${ }^{1}$ Section of Geotechnical Engineering, Department of Civil Engineering, Democritus University of \\ Thrace,67100Xanthi,fpliakas@civil.duth.gr,akall@civil.duh.gr,jdiam@civil.duth.gr
}

\begin{abstract}
This paper investigates the progress of groundwater salinization within the plain area of Xilagani-Imeros, in SW part of Rhodope Prefecture, as well as the suitability of groundwater for drinking and irrigation use, after qualitative classification of groundwater samples from selective wells of the study area based on relevant guidelines. Some managerial suggestions for the confrontation of the seawater intrusion regime of the study area are also included. The investigation in question took place between 1994-1997 and 2002-2006, and involved drilling of test wells, geoelectric sounding measurements, grain size analyses, elaboration of hydrological data, monitoring and relevant analysis of the groundwater level fluctuations in selective wells, electrical conductivity measurements as well as conducting chemical analyses of water samples from selective wells of the study area and relevant elaboration.
\end{abstract}

Key words: coastal aquifers, sea water intrusion, groundwater quality.

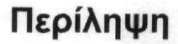

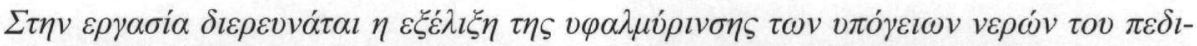

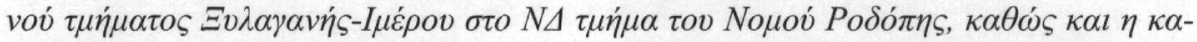

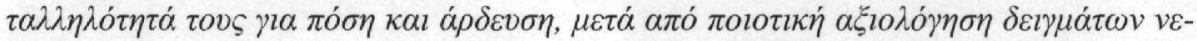

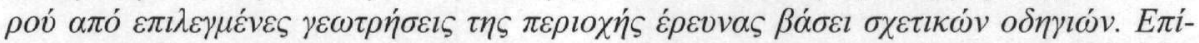

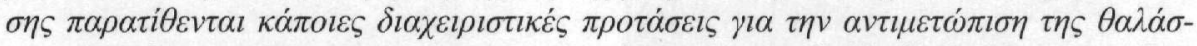

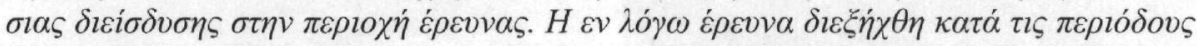

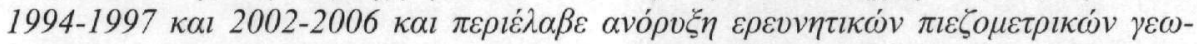

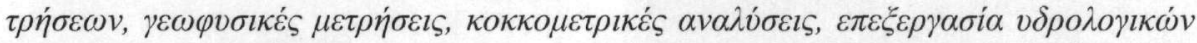

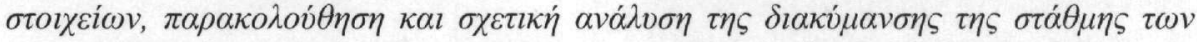

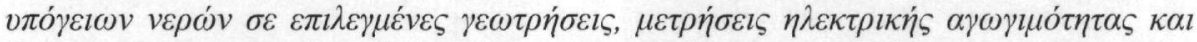

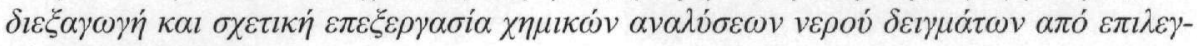

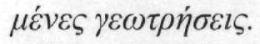

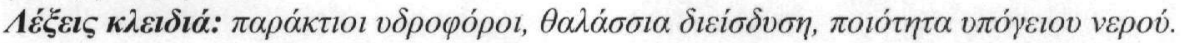

\section{Introduction}

This paper aims to the investigation of the advance of the seawater front within the plain area of Xilagani - Imeros, at the SW part of Rhodope Prefecture, analyses the groundwater quality of selected samples in terms of their suitability for different uses and finally results in appropriate pro- 
posals for the management of groundwater resources of the area. The study in question includes: a) research activities for the period 20/2/1994-7/12/1997, during relevant research project carried out for the Greek Ministry of Agriculture, by the Laboratories of Engineering Geology and Hydraulics of the Department of Civil Engineering - Democritus University of Thrace, regarding the management of artificial recharge of aquifers in Xanthi and Rhodope (Pliakas et al. 2001, Sakkas et al. 1998), and b) relevant research activities of the Laboratory of Engineering Geology of the Department of Civil Engineering - Democritus University of Thrace during the period 17/12/20029/10/2006 (Mouzaliotis 2006, Pliakas et al. 2004).

\section{Physical environment, corps, hydrological and hydrogeological data}

The plain area of Xilagani - Imeros has mild morphologic characteristics with low elevation, extended between Lissos River and the western foot of Ismaros Mount, whereas Thracian Sea covers the southern boundaries of the area (Fig. 1). The geological environment of the study area includes recent sediments originated from Lissos River -and some other branches of the same river- overlying neogene deposits or palaiogene deposits of Rhodope massif.

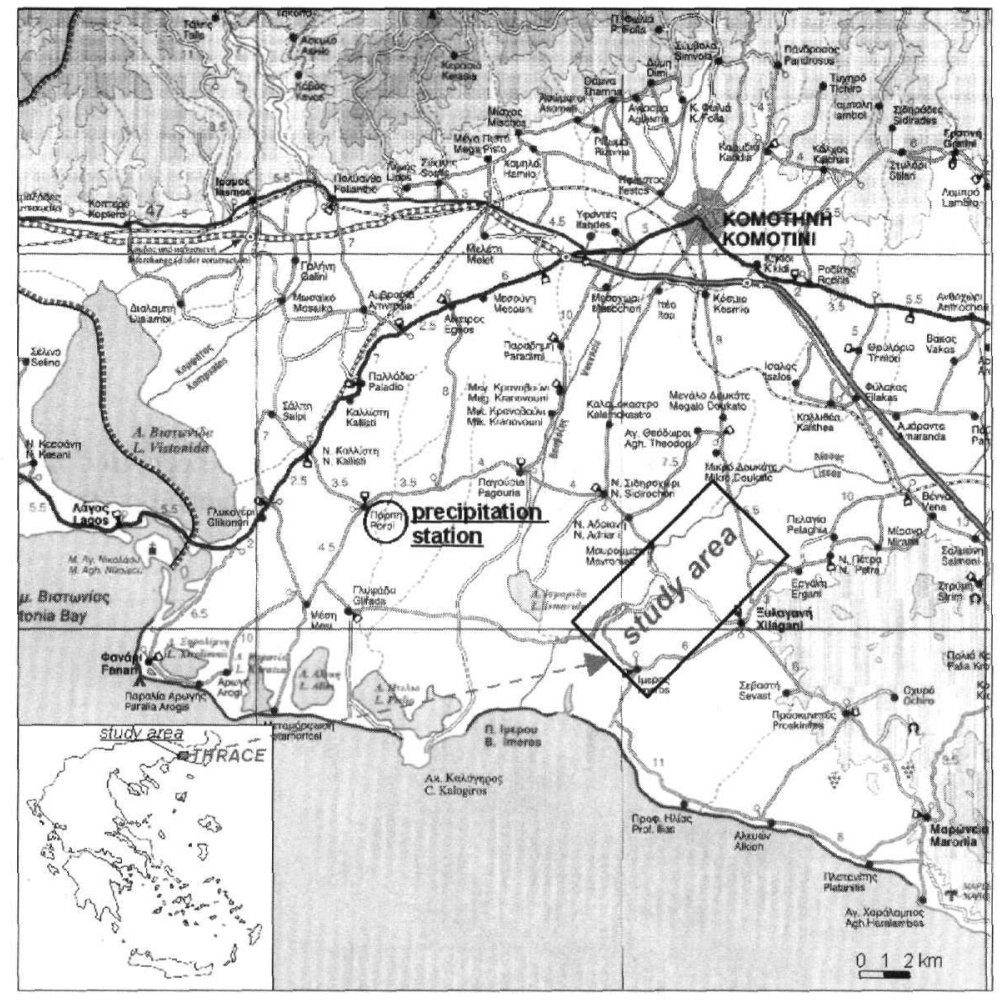

Figure 1 - Study area and position of the Porpi precipitation station

The groundwaters of the coastal area of investigation provide the demanded amounts of water for the irrigation needs of the site. The main cultivation type of the area is cotton, while the southern part of the area of investigation is not arable due to groundwater salinisation.

The elaboration of the precipitation data for the precipitation station of Porpi, for the period 19542005 , located at the southern part of Rhodope Prefecture (fig. 1) which is thought to be representative of the study area, concluded the following (Figs 2, 3): 
- The mean monthly rainfall has maximum value in December $(87.5 \mathrm{~mm})$ and minimum value in August (13.4 mm), while the maximum recorded value of rainfall occurred in December of 1969 (323.4 mm),

- The maximum annual rainfall values are observed during the years 1960 (854.4 mm), 1966 (843.9 mm), 1954 (891.5 $\mathrm{mm})$ and $1979(922.0 \mathrm{~mm})$,

- The annual rainfalls for the period 1990-1994 are less than the mean annual rainfall of the period 1954-2005 (554.9 mm), while the values of the period 1995-2001 are greater (1998 excluded), although they appear to decline in each year,

- After the year 2002, the values of rainfall appear significantly increased compared to the ones during the last 15 years.

The area of investigation includes 55 groundwater wells (about 10 of them abandoned), with mean depth of $70 \mathrm{~m}$ and mean pumping rate of approximately $40 \mathrm{~m}^{3} / \mathrm{h}$, while at the northern parts of the site the groundwater wells present pumping rates of approximately 60 to $70 \mathrm{~m}^{3} / \mathrm{h}$. The aquifer system of the study area contains clay materials and appears in the form of successive layers composed of clay-sands and sands with a width ranging from 1 to $10 \mathrm{~m}$, with many interferences of clay layers.

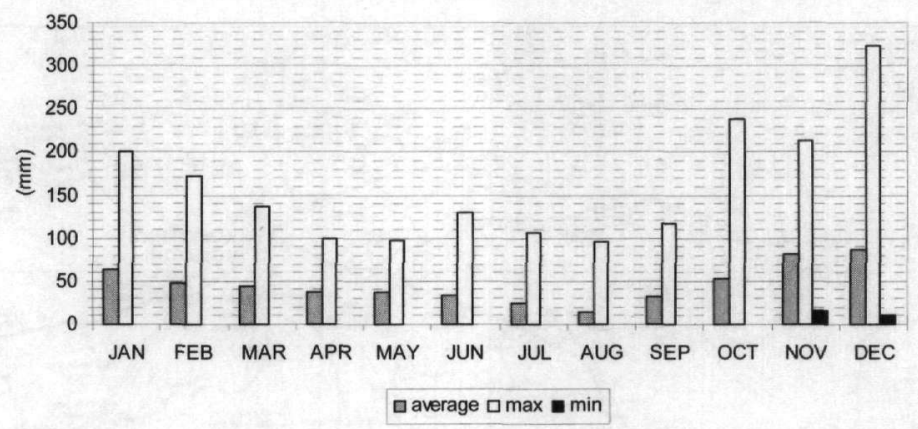

Figure 2 - Average, maximum and minimum precipitation values recorded in Porpi precipitation station during the period 1954-2005 (Mouzaliotis 2006)

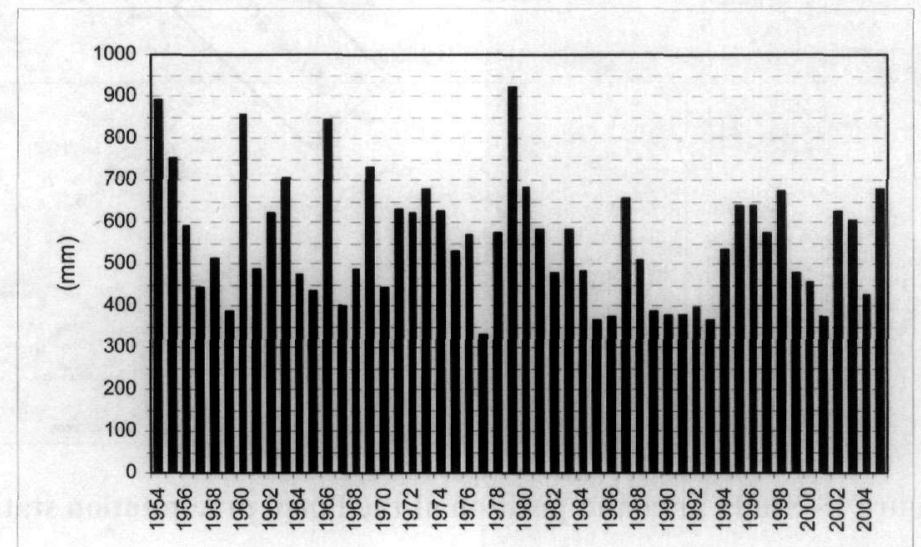

Figure 3 - Fluctuation of annual precipitation values for the period 1954 - 2005

\section{Hydrogeological study}

The relevant hydrogeological study of the semi-confined aquifer of the study area included the following research activities: 
1. Drilling of 6 test wells at depths $45-70 \mathrm{~m}$ (Figs 4 A, B), performance of 20 geophysical (electrical sounding) measurements (Figs $4 \mathrm{~A}, \mathrm{C}$ ) and grain size analyses of 25 soil samples. The results showed 4 distinct main geoelectrical formations categorized according to the values of their specific electrical resistivity, as follows (ASCE 1987, Kallergis 1986): (1) coarse grained sand ( $>40$ $\mathrm{Ohm} \times \mathrm{m})$, (2) fine grained sand (25-40 Ohm $\times \mathrm{m})$, (3) clay-sand materials (15-25 $\mathrm{Ohm} \times \mathrm{m})$, (4) clay $(<15 \mathrm{Ohm} \times \mathrm{m})$, while the dominance of clay and clay-sand materials throughout the whole extent of the study site is very distinct (Pliakas et al. 2001, Sakkas et al. 1998).

2. Monitoring of groundwater level (above sea level, a.s.1.) fluctuation from 24 wells which are evenly distributed in the area, on a frequent basis during the period 20/2/1994-7/12/1997 (Pliakas et al. 2001, Sakkas et al. 1998), as well as from a recently designed network of 25 wells (10 are common with the previous network) during the period 17/12/2002-9/10/2006 (Fig. 4). The produced graphs of the groundwater level (a.s.l.) fluctuation for the second period of investigation (18 are shown in Fig. 5) show that:

- The groundwater level fluctuation for the majority of the monitoring wells shows the relation between the piezometric levels and the pumping and recharge periods. The groundwater level gradually increases from October to March, due to natural recharge from direct infiltration from precipitation (at parts of the aquifer where it appears semi-confined or unconfined), percolation from Lissos River and lateral inflows from the NE part of the study area where there is a hydraulic connection with the mountaineous zone. During the period between April and October the groundwater level appears below the mean sea level fact which is attributed to the overpumping conditions for irrigation purposes.

- Wells 2, 6, 8 and 23 do not show significant groundwater level fluctuation during the year (the fluctuation ranges between 0.50 and $1.50 \mathrm{~m}$ ), fact which is attributed to:

- well 6 is an abandoned well,

- wells 2 and 8 are located within a part of the study area adjacent to Mount Ismaros, where groundwater replenishment is achieved even during the irrigation periods (presence of the NE main recharge axis presented in the piezometric maps of Figs 6,7),

- well 23, is located close (approximately $10 \mathrm{~m}$ ) to a small surface water basin, which is connected with a ditch extended across the eastern part of the study area and was activated on 2003 resulting to a groundwater level increase at the surrounding area of the well.

- Wells: 12, 15, 16, 19, 20, 22 and 25 show groundwater levels below sea level during the entire year, apart from the period between February and March. The above corroborate the argument that the aquifer system of investigation is subjected to seawater conditions regime.

3. The piezometric maps designed for the period 17/12/2002-9/10/2006 (4 presented in Figs 6, 7), show 2 main groundwater recharge axes, the one located at the NE boundary of the area (main freshwater recharge axis of the study aquifer system from the mountaineous zone) and the other located at the SW part of the study site (percolation from Lissos River). The latter one appears increased from 2003, fact which is attributed to the deepening of a local ditch at that region. Additionally it is observed that the southern part of the study area shows a piezometric surface which is constantly below sea level during the entire year (apart from the period between February and March). The fact above, together with the observation that the piezometric surface of the aquifer in March and April of the years 2005 and 2006 is above mean sea level, leads to the conclusion that the aquifer system is incapable to respond to the amounts of pumped groundwater during the irrigation period maintaining at the same time a piezometric surface above sea level. 


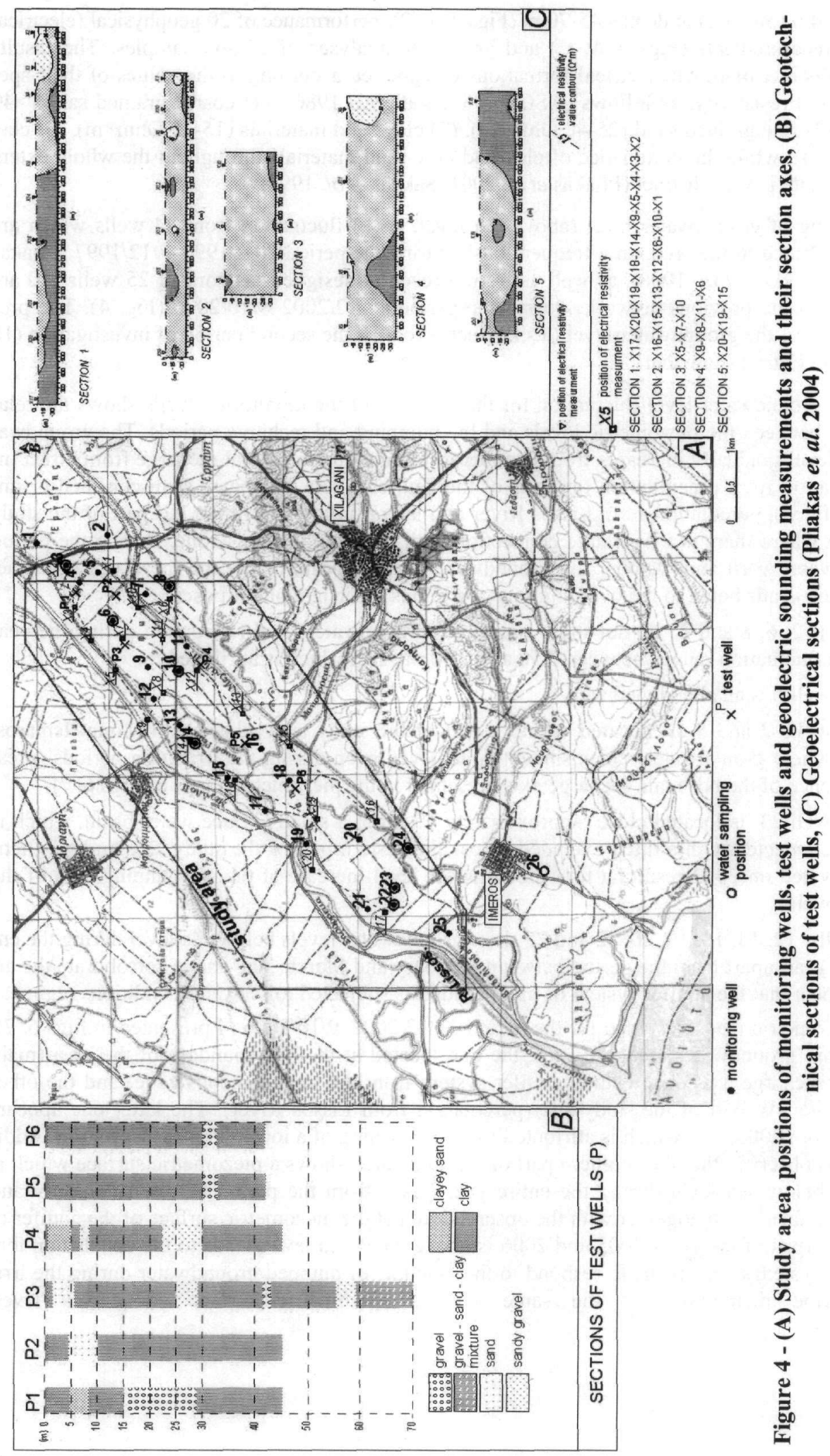




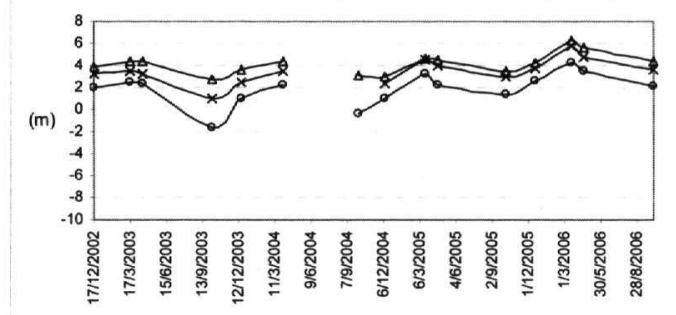

$\rightarrow 1 \rightarrow 2 \rightarrow 3$

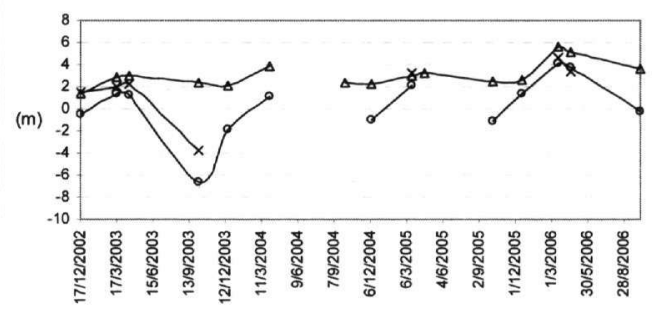

$\triangle 8 \rightarrow-6 \rightarrow 10$

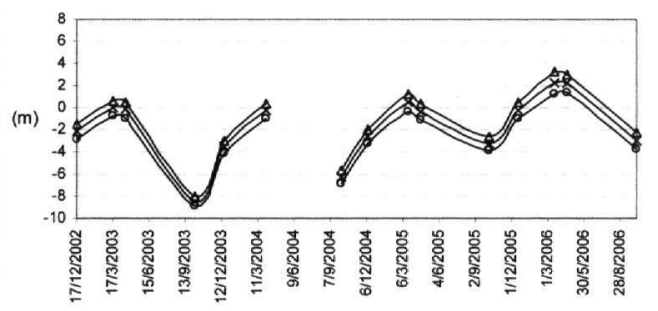

$\triangle 16 \rightarrow-19 \multimap 20$

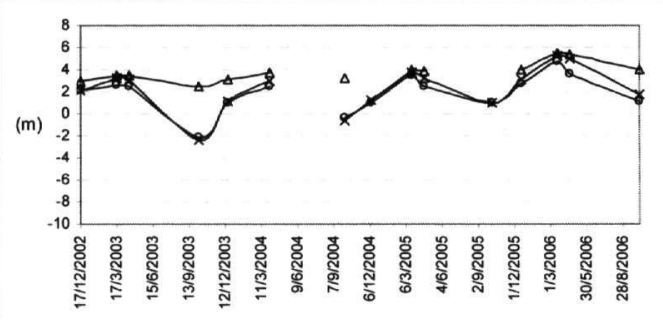

$\rightarrow 4 \rightarrow 6 \rightarrow-7$
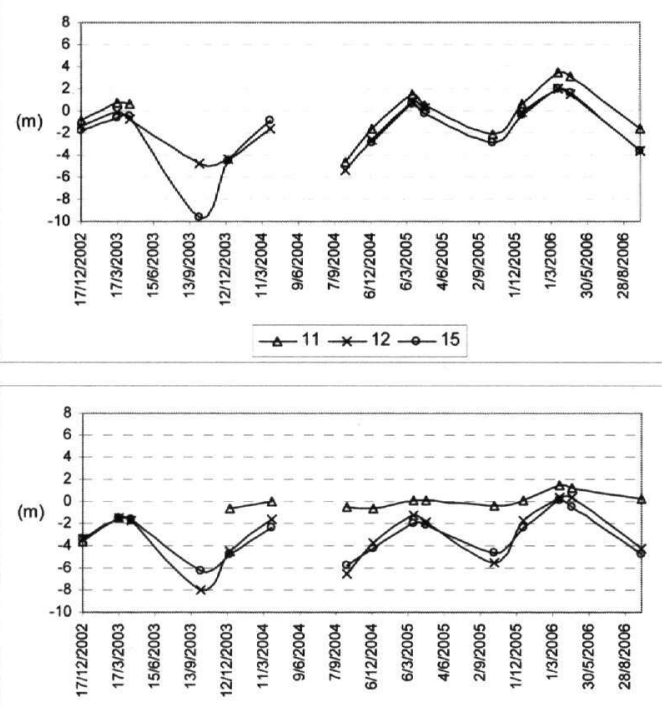

$\rightarrow 22 \bowtie-23 \rightarrow 25$

Figure 5 - Fluctuation of groundwater level of selected monitoring wells (m a.s.l.)

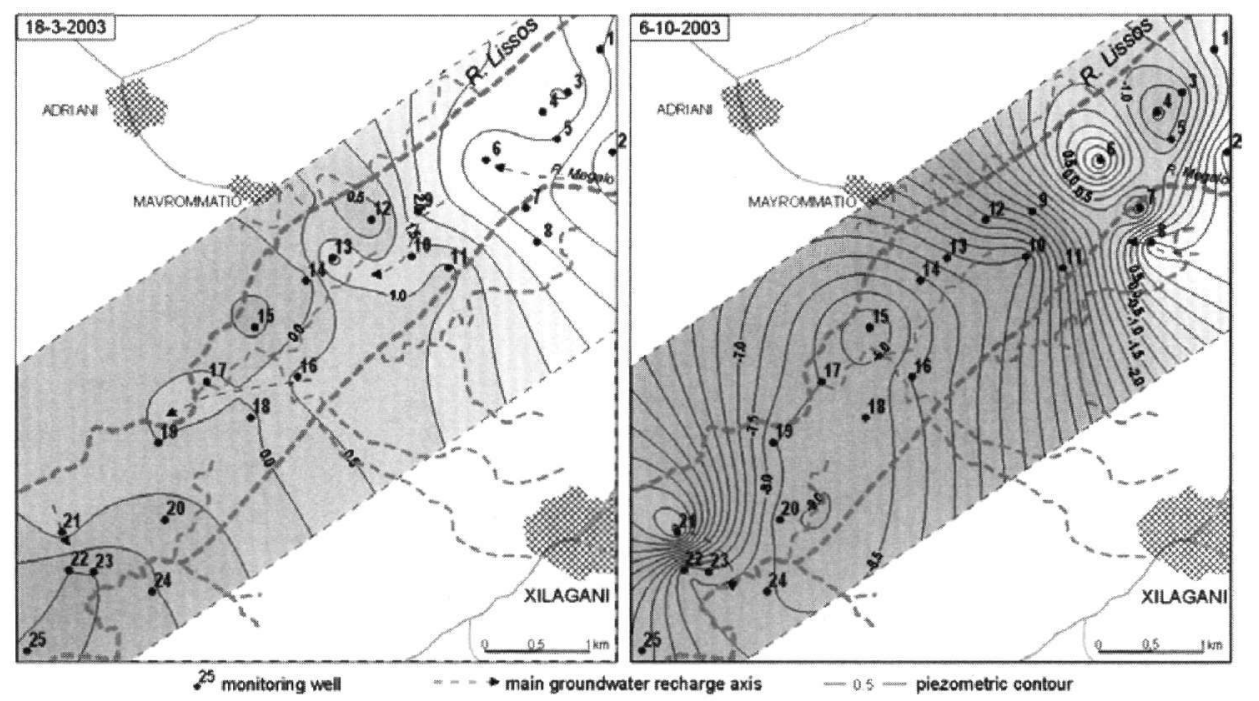

Figure 6 - Piezometric maps (m a.s.l.) of the Xilagani - Imeros aquifer system (March and October of the year 2003) (Mouzaliotis 2006) 


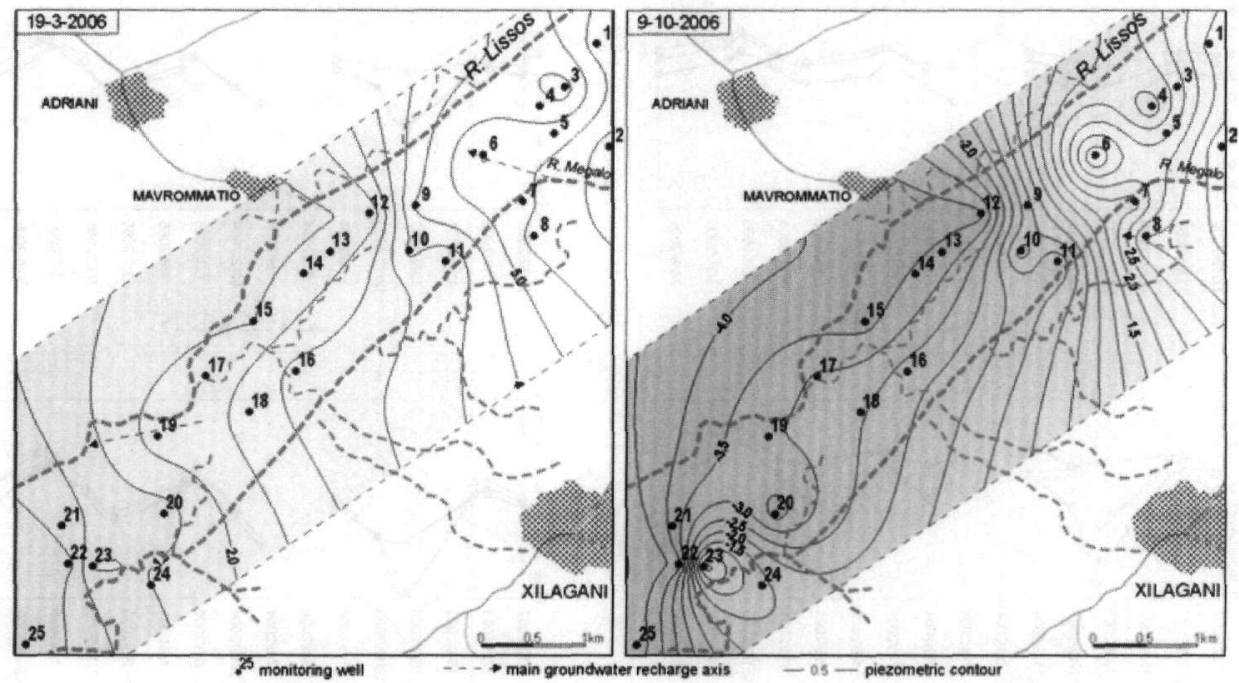

Figure 7 - Piezometric maps (m a.s.I.) of the Xilagani - Imeros aquifer system (March and October of the year 2006) (Mouzaliotis 2006)

\section{Groundwater quality}

The qualitative investigation of the study aquifer, initially involved the in situ measurements of electrical conductivity from 24 groundwater wells (on 20/8/1994) and from 50 groundwater wells (in 22/8/1995) (Pliakas et al. 2001, Sakkas et al. 1998), as well as in 8/7/2003, 31/7/2005 and 20-72006 from 15 groundwater wells (Fig. 8). The values of electrical conductivity range between 800$3,000 \mu \mathrm{S} / \mathrm{cm}$ for the first measurement series and $880-12,380 \mu \mathrm{S} / \mathrm{cm}$ for the next three measurement series, where the higher values of electrical conductivity appear within the southerN (coastal) part of the study site. The comparison of a series of measurements during the periods 1994-1995 and 2003-2006 reveals high values of the southern part of the study area, fact which imposes the argument of seawater intrusion conditions.
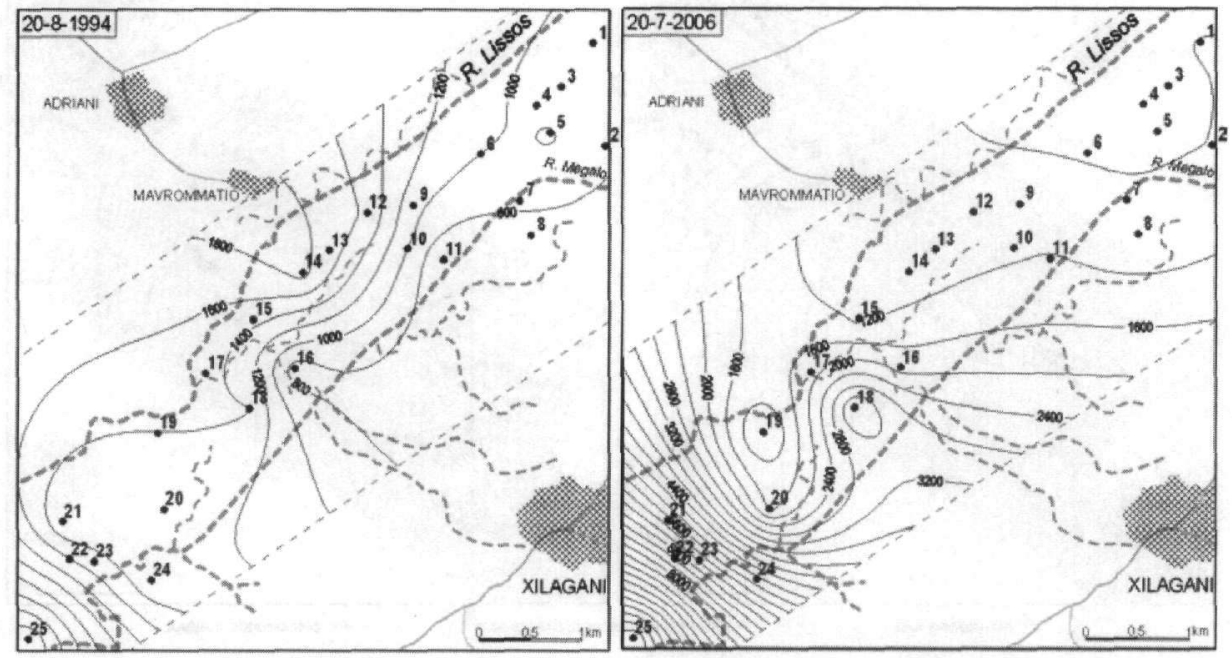

Figure 8 - Distribution of Electrical Conductivity (EC) $(\mu \mathrm{S} / \mathrm{cm})$ measured on 20/8/1994 and 20/7/2006 (Pliakas et al. 2004, Mouzaliotis 2006) 
Table 1 - Results of chemical analyses of groundwater samples from selected wells on 8/7/2003 (Pliakas et al., 2004) and 20/7/2006 (Mouzaliotis 2006). Highlighted concentrations higher than the maximum allowable levels (drinking water standards from Kallergis 2000)

\begin{tabular}{|c|c|c|c|c|c|c|c|c|c|c|c|c|}
\hline 8-7-2003 & $\begin{array}{r}\mathrm{Ca}^{2+} \\
(* 1) \\
(m g / L) \\
\end{array}$ & $\begin{array}{c}\mathrm{Mg}^{2+} \\
\left({ }^{2+} 2\right) \\
(m g / L)\end{array}$ & $\begin{array}{c}\mathrm{Na}^{+} \\
\left({ }^{*} 3\right) \\
(m g / L) \\
\end{array}$ & $\begin{array}{c}\mathrm{K}^{+} \\
\left({ }^{*} 4\right) \\
(m g / L) \\
\end{array}$ & $\begin{array}{l}\mathrm{Mn}^{2+} \\
(m g / L) \\
\end{array}$ & $\begin{array}{l}\mathrm{Fe}^{2+} \\
(m g / L)\end{array}$ & $\begin{array}{l}\mathrm{Zn}^{2+} \\
(m g / L)\end{array}$ & \begin{tabular}{r|}
$\mathrm{NH}_{4}^{+}$ \\
$\left({ }^{+} 5\right)$ \\
$(m g / L)$ \\
\end{tabular} & $\begin{array}{c}\mathrm{HCO}_{3}{ }^{*} \\
\left({ }^{*} 6\right) \\
(m g / L)\end{array}$ & $\begin{array}{c}\mathrm{Cl}^{-} \\
\left({ }^{*} 7\right) \\
(m g / L)\end{array}$ & $\begin{array}{c}\mathrm{SO}_{4}^{2-} \\
\left({ }^{*} 8\right) \\
(m g / L) \\
\end{array}$ & \\
\hline 3 & 70.54 & 32.50 & 116.00 & 10.50 & 0.00 & 0.00 & 0.00 & 0.00 & 396.50 & 116.00 & 10.50 & \\
\hline 6 & 68.94 & 156.73 & 100.00 & 6.60 & 0,0 & 0.00 & 0.00 & 0.00 & 350.14 & 425.00 & 58.00 & \\
\hline 8 & 84.97 & 45.68 & 58.00 & 5.00 & 0.00 & 0.00 & 0.00 & 1.15 & 318.42 & 354.50 & 92.00 & \\
\hline 10 & 110.22 & 25.70 & 318.00 & 86.00 & 0.00 & 0.00 & 0.00 & 2.14 & 313.54 & 992.00 & 88.00 & \\
\hline 14 & 36.87 & 15.55 & 200.00 & 8.50 & 0.00 & 0.00 & 0.00 & 0.00 & 390.40 & 496.00 & 60.00 & \\
\hline 22 & 332.67 & 206.55 & 726.00 & 27.00 & 0.00 & 0.00 & 0.00 & 0.00 & 337.94 & 2375.00 & 128.00 & \\
\hline 23 & 232.47 & 133.65 & 400.00 & 15.00 & 0.00 & 0.00 & 0.00 & 0.00 & 341.60 & 1418.00 & 83.60 & \\
\hline 24 & 52.21 & 37.00 & 208.00 & 18.00 & 0.00 & 0.00 & 0.00 & 0.00 & 366.00 & 709.00 & 75.05 & \\
\hline 26 & 497.00 & 175.00 & 481.00 & 3.00 & 0.00 & 0.00 & 0.00 & 0.10 & 247.66 & 1773.00 & 300.00 & \\
\hline well & $\begin{array}{c}\mathrm{NO}_{3}^{-} \\
\left({ }^{*} \mathrm{*}\right) \\
(m g / L)\end{array}$ & $\begin{array}{c}\mathrm{NO}_{2}^{-} \\
\left({ }^{*} 10\right) \\
(m g / L)\end{array}$ & $\begin{array}{l}\mathrm{PO}_{4}{ }^{3} \\
(\mathrm{mg} / \mathrm{L})\end{array}$ & $\mathrm{pH}$ & $\begin{array}{c}\text { EC } \\
(\mu \mathrm{S} / \mathrm{cm})\end{array}$ & $\begin{array}{c}\text { Alkalinity } \\
\mathrm{P}\end{array}$ & $\begin{array}{c}\text { Alkalinity } \\
\mathrm{M}\end{array}$ & \begin{tabular}{|c|}
$\begin{array}{c}\text { Temp. } \\
\text { Hardness } \\
\left({ }^{\circ} \mathrm{F}\right)\end{array}$ \\
\end{tabular} & $\begin{array}{c}\text { Perm. } \\
\text { Hardness } \\
\left({ }^{\circ} F\right)\end{array}$ & $\begin{array}{c}\text { Total } \\
\text { Hardness } \\
\left({ }^{\circ} \mathrm{F}\right) \\
\end{array}$ & $S A R^{\star \star}$ & $\begin{array}{l}\text { TDS } \\
\text { (mg/L) }\end{array}$ \\
\hline 3 & 2.00 & 0.00 & 0.90 & 8.11 & 1162 & 0.00 & 6.50 & 32.50 & 4.30 & 36.80 & 2.87 & 720.4 \\
\hline 6 & 1.50 & 0.00 & 0.90 & 7.87 & 1197 & 0.00 & 5.74 & 28.70 & 53.00 & 81.70 & 1.52 & $742,$. \\
\hline 8 & 14.00 & 0.06 & 0.95 & 8.20 & 933 & 0.00 & 5.22 & 26.10 & 13.90 & 40.00 & 1.26 & 578.4 \\
\hline 10 & 0.00 & 0.00 & 1.26 & 7.99 & 2440 & 0.00 & 5.14 & 25.70 & 27.80 & 53.50 & 7.09 & 1512.7 \\
\hline 14 & 1.00 & 0.00 & 2.69 & 7.98 & 1384 & 0.00 & 6.40 & 32.00 & 0.00 & 15.60 & 6.97 & 858.0 \\
\hline 22 & 3.00 & 0.00 & 0.23 & 7.89 & 6895 & 0.00 & 5.54 & 27.70 & 140.30 & 168.00 & 7.71 & 4274.6 \\
\hline 23 & 1.00 & 0.00 & 0.45 & 7.99 & 4290 & 0.00 & 5.60 & 28.00 & 86.00 & 114.00 & 5.18 & 2659.6 \\
\hline 24 & 3.00 & 0.00 & 0.21 & 7.78 & 1802 & 0.00 & 6.00 & 30.00 & 11.20 & 41.20 & 5.38 & 1117.2 \\
\hline 26 & 21.00 & 0.00 & 0.24 & 7.34 & 6100 & 0.00 & 4.06 & 20.30 & 0.00 & 19.60 & 4.73 & 3781.8 \\
\hline
\end{tabular}

\begin{tabular}{|c|c|c|c|c|c|c|c|c|c|c|c|c|}
\hline $20-7-2006$ & $\begin{array}{c}\mathrm{Ca}^{2+} \\
\left({ }^{*} 1\right) \\
(m g / L) \\
\end{array}$ & $\begin{array}{c}\mathrm{Mg}^{2+} \\
\left({ }^{2} 2\right) \\
(m g / L)\end{array}$ & $\begin{array}{c}\mathrm{Na}^{+} \\
\left({ }^{*} 3\right) \\
(m g / L) \\
\end{array}$ & $\begin{array}{c}\mathrm{K}^{+} \\
\left({ }^{*} 4\right) \\
(m g / L)\end{array}$ & $\begin{array}{l}\mathrm{Mn}^{2+} \\
(\mathrm{mg} / \mathrm{L})\end{array}$ & $\begin{array}{l}\mathrm{Fe}^{2+} \\
(m g / L)\end{array}$ & $\begin{array}{l}\mathrm{Zn}^{2+} \\
(m g / L)\end{array}$ & $\begin{array}{c}\mathrm{NH}_{4}^{+} \\
\left.{ }^{+}{ }^{+} 5\right) \\
(m g / L)\end{array}$ & $\begin{array}{c}\mathrm{HCO}_{3}{ }^{*} \\
\left.{ }^{*} 6\right) \\
(m g / L) \\
\end{array}$ & $\begin{array}{c}\mathrm{Cl}^{-} \\
\left({ }^{*} 7\right) \\
(\mathrm{mg} / \mathrm{L})\end{array}$ & $\begin{array}{c}\mathrm{SO}_{4}{ }^{2-} \\
\left.{ }^{*} 8\right) \\
(m g / L) \\
\end{array}$ & \\
\hline 2 & 54.90 & 37.75 & 51.00 & 5.00 & 0.00 & 0.06 & 0.00 & 0.41 & 289.14 & 57.80 & 79.00 & \\
\hline 8 & 69.36 & 40.82 & 76.00 & 8.00 & 0.00 & 0.20 & 0.00 & 1.03 & 324.52 & 78.70 & 90.00 & \\
\hline 11 & 55.30 & 44.70 & 26.00 & 10.00 & 0.00 & 0.85 & 0.00 & 0.77 & 419.68 & 113.83 & 82.00 & \\
\hline 15 & 32.87 & 21.38 & 40.00 & 5.00 & 0.00 & 0.27 & 0.00 & 1.23 & 263.52 & 179.43 & 53.00 & \\
\hline 16 & 52.90 & 70.95 & 52.00 & 10.00 & 0.00 & 0.07 & 0.00 & 1.60 & 379.42 & 292.54 & 77.00 & \\
\hline 18 & 87.37 & 85.05 & 107.00 & 10.00 & 0.00 & 0.19 & 0.00 & 1.00 & 405.04 & 833.60 & 67.00 & \\
\hline 19 & 17.47 & 31.83 & 74.00 & 7.00 & 0.00 & 0.33 & 0.00 & 1.11 & 308.66 & 80.85 & 61.00 & \\
\hline 20 & 56.51 & 55.40 & 43.00 & 5.00 & 0.00 & 0.11 & 0.00 & 0.71 & 446.52 & 276.59 & 82.00 & \\
\hline 25 & 462.00 & 414.00 & 1812.50 & 30.00 & 0.00 & 1.31 & 0.00 & \begin{tabular}{|l|}
8.40 \\
\end{tabular} & 287.92 & \begin{tabular}{|l|}
4184.28 \\
\end{tabular} & 0.00 & \\
\hline well & $\begin{array}{c}\mathrm{NO}_{3}^{-} \\
\left({ }^{*} 9\right) \\
(m g / L)\end{array}$ & $\begin{array}{c}\mathrm{NO}_{2}^{-} \\
\left({ }^{*} 10\right) \\
(m g / L)\end{array}$ & $\begin{array}{l}\mathrm{PO}_{4}^{3-} \\
(\mathrm{mg} / \mathrm{L})\end{array}$ & $\mathrm{pH}$ & $\begin{array}{c}\mathrm{EC} \\
(\mu \mathrm{S} / \mathrm{cm})\end{array}$ & $\begin{array}{l}\text { Alkalinity } \\
\mathrm{P}\end{array}$ & $\begin{array}{c}\text { Alkalinity } \\
\mathrm{M}\end{array}$ & $\begin{array}{c}\text { Temp. } \\
\text { Hardness } \\
\left({ }^{\circ} \mathrm{F}\right)\end{array}$ & $\begin{array}{c}\text { Perm. } \\
\text { Hardness } \\
\left({ }^{\circ} \mathrm{F}\right)\end{array}$ & $\begin{array}{c}\text { Total } \\
\text { Hardness } \\
\left({ }^{\circ} \mathrm{F}\right)\end{array}$ & SAR ${ }^{\star * *}$ & $\begin{array}{l}\text { TDS }^{\text {*** }} \\
(m g /))\end{array}$ \\
\hline 2 & 18.00 & 0.22 & 0.45 & 7.47 & 808 & 0.00 & 4.74 & \begin{tabular}{|l|}
23.70 \\
\end{tabular} & 4.30 & 28.00 & 1.3 & 525.2 \\
\hline 8 & 12.00 & 0.07 & 1.20 & 7.69 & 921 & 0.00 & 5.32 & 26.60 & 7.20 & 33.80 & 3.58 & 598.7 \\
\hline 11 & 5.00 & 0.03 & 0.60 & 7.23 & 1245 & 0.00 & 6.88 & 34.40 & 0.00 & 32.20 & 0.63 & 809.2 \\
\hline 15 & 3.00 & 0.02 & 2.37 & 7.46 & 1138 & 0.00 & 4.32 & 21.60 & 0.00 & 17.00 & 1.33 & 739.7 \\
\hline 16 & 22.00 & 0.03 & 0.77 & 7.86 & 1879 & 0.00 & 6.22 & 31.10 & 11.30 & 42.40 & 1.1 & 1221.4 \\
\hline 18 & 5.00 & 0.02 & 1.10 & 7.58 & 3660 & 0.00 & 6.64 & 33.20 & 23.60 & 56.80 & 1.95 & 2379 \\
\hline 19 & 3.00 & 0.02 & 0.70 & 7.74 & 733 & 0.00 & 5.06 & 25.80 & 0.00 & 21.80 & 2.44 & 476.5 \\
\hline 20 & 4.00 & 0.10 & 1.31 & 7.37 & 1525 & 0.00 & 7.32 & 36.60 & 0.30 & 36.90 & 0.97 & 991.2 \\
\hline 25 & 3.00 & 0.05 & 0.00 & 7.35 & 12380 & 0.00 & 7.72 & 23.60 & 238.60 & 262.00 & 14.75 & 8047 \\
\hline
\end{tabular}

max concentration levels: *1: $<75 \mathrm{mg} / \mathrm{L}, * 2:<50 \mathrm{mg} / \mathrm{L}, * 3:<200 \mathrm{mg} / \mathrm{L}, * 4:<12 \mathrm{mg} / \mathrm{L}, * 5:<0.50 \mathrm{mg} / \mathrm{L}, * 6$ : (usually) $<500 \mathrm{mg} / \mathrm{L}, * 7:<250 \mathrm{mg} / \mathrm{L}, * 8:<250 \mathrm{mg} / \mathrm{L}, * 9:<50 \mathrm{mg} / \mathrm{L}, * 10:<0.50 \mathrm{mg} / \mathrm{L}$

The evaluation and assessment of the qualitative characteristics of the groundwater samples of the study aquifer from selected wells occurred on 8/7/2003 and 20/7/2006 and the chemical analyses took place at the Laboratory of Engineering Geology of the Civil Engineering Department of Democritus University of Thrace. The chemical analyses involved the determination of certain chemical parameters, such as $\mathrm{Na}^{+}, \mathrm{K}^{+}, \mathrm{Ca}^{2+}, \mathrm{Mg}^{2+}, \mathrm{Fe}^{2+}, \mathrm{Zn}^{2+}, \mathrm{Mn}^{2+}, \mathrm{NH}_{4}^{+}, \mathrm{Cl}^{-}, \mathrm{HCO}_{3}^{-}, \mathrm{SO}_{4}^{2-}$, 
$\mathrm{PO}_{4}{ }^{3-}, \mathrm{NO}_{3}{ }^{-}, \mathrm{NO}_{2}{ }^{-}$, and certain physicochemical parameters such as alkalinity $\mathrm{P}$, alkalinity $\mathrm{M}$, total hardness and $\mathrm{pH}$ (Table 1, Fig. 4).

The majority of the groundwater samples of the investigated aquifer, according to specific standards and drinking water limits (Kallergis, 2000), are characterized as non-potable, as the concentrations of $\mathrm{Cl}^{-}, \mathrm{Na}^{+}, \mathrm{K}^{+}, \mathrm{Ca}^{2+}, \mathrm{Mg}^{2+}$ are above the quality standards (Table 1, bold typed).

The comparison of the results of the chemical analyses which took place during the irrigation periods of 2003 and 2006 shows that the quality of the groundwaters originated from the northern part of the study area is significantly improved in 2006. This argument is illustrated from the distribution of the chloride ions concentration, in fig. 9 , where the values of $\left[\mathrm{Cl}^{-}\right]$mainly at the central and more significantly at the NE part of the study area -the ones which refer to 2006- appear much decreased. Wells $2,3,8$ and 19 show strong $\left[\mathrm{Na}^{+}\right]$excess with respect to $\left[\mathrm{Cl}^{-}\right]$, which points to freshening processes instead of salinization ones in the locations where those wells are drilled. However, the values of $\left[\mathrm{Cl}^{-}\right]$at the SW part of the area reach $4184 \mathrm{mg} / \mathrm{L}$ (2006), fact which is attributed to the seawater intrusion conditions. This can be correlated with the aforementioned observations which refer to the fluctuation of the groundwater levels of the aquifer system (Ffig. 5) and the distribution of the electrical conductivity (Fig.8), as well as with the presence of two main recharge axes as appear in the piezometric maps of fig. 6 and 7 . The above are additionally related to the increase of the rainfall heights (and therefore of the natural recharge conditions) during the period 2005-2006 (Fig. 3). Therefore it is observed that the NE part shows increased lateral freshwater recharge of the aquifer (originated from the foot of Ismaros Mount) whereas the SW part shows increased qualitative degradation due to seawater intrusion regime.
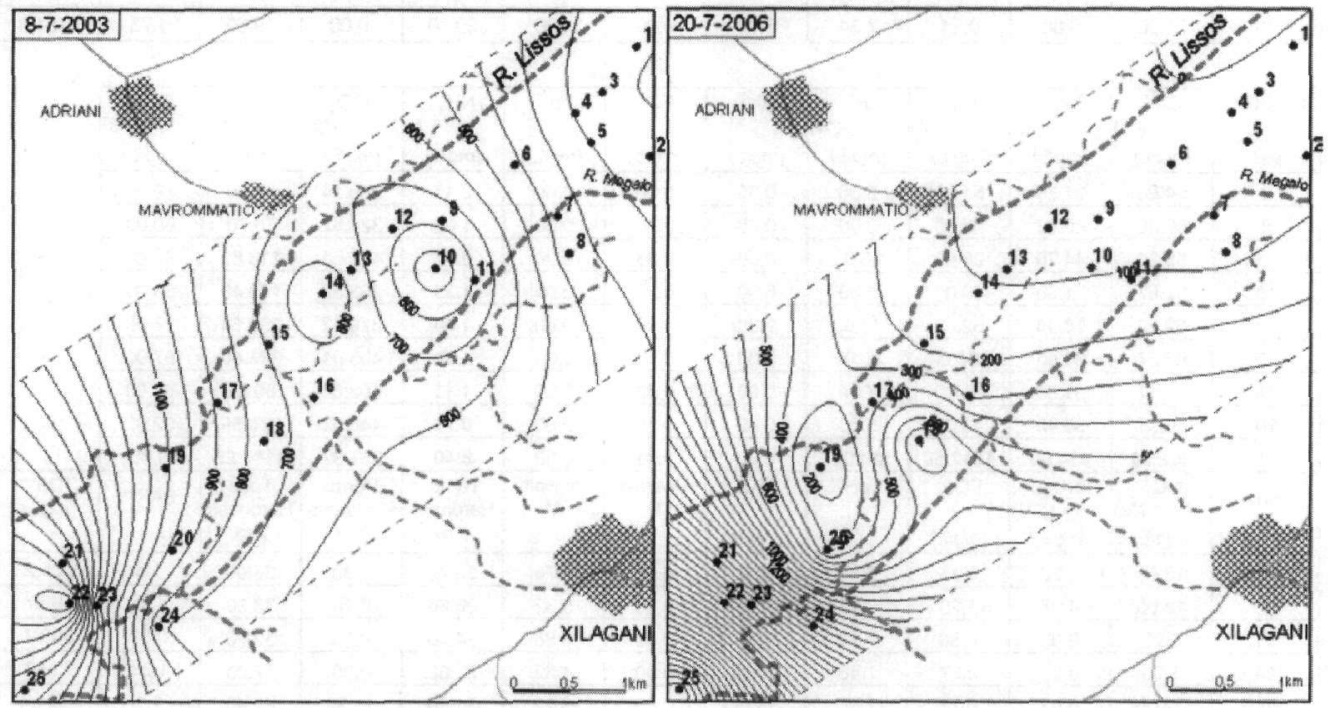

Figure 9 - Distribution of chloride $\left(\mathrm{Cl}^{-}\right)$concentration $(\mathrm{mg} / \mathrm{L})$ on 8/7/2003 and 20/7/2006 (Mouzaliotis 2006)

Fig. $10 \mathrm{~A}$ and B include trilinear diagrams, according to Piper (1944), of the samples of the area and provide an interpretation of the chemical analyses of both sampling periods (2003 and 2006 respectively), where it is concluded that chloride is the dominant anion for the majority of the groundwater samples in 2003 while the same feature applies to only two of the groundwater samples of the area in 2006. This fact verifies the previous ascertainment that the extent of seawater intrusion front was greater during the irrigation period of 2003.

The groundwater samples of the study aquifer were evaluated in terms of their qualitative characteristics according to the values of Sodium Adsorption Ratio, SAR, Total Dissolved Solids, TDS, 
Electrical Conductivity, EC, and the concentrations of specific ions such as $\mathrm{Na}^{-}, \mathrm{Cl}^{-}$and $\mathrm{HCO}_{3}{ }^{-}$ (Table 2). The Degree of Restriction on Use (DRU) (Asano and Pettygrove 1987, Roscoe Moss Company 1990) appears as follows:

- regarding salinity (affecting of water to crop) as Slight to Moderate (SM) in the majority of groundwater samples, and Serious (S) for some of them,

- regarding permeability (affecting infiltration rate of water into the soil) as None (N) to Slight to Moderate (SM) while the samples of 2006 appear qualitatively improved,

- regarding specific ion toxicity (affecting sensitive crops) as None (N) to Serious (S) with characteristic the use of sprinkler irrigation where the majority of the groundwater samples are evaluated as Slight to Moderate DRU.

Most of the samples are characterized problematic, as 34 values are marked as N, 20 as S and 90 as SM out of 144 DRU values.

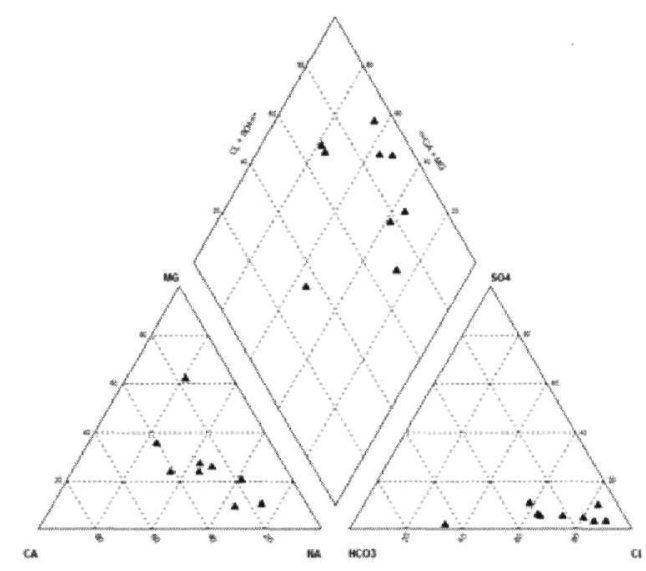

(A)

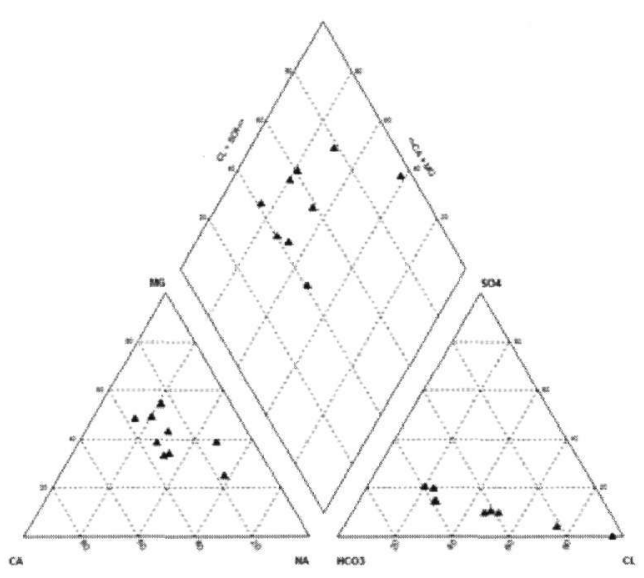

(B)

Figure 10 - Piper diagrams representing the results of chemical analyses of groundwater samples taken on (A) 8/7/2003 and (B) 20/7/2006

\section{Further research and managerial proposals}

The next step of enriching substantially the detailed elaboration of the seawater problem in the study area should focus on aspects related to:

- conceptual model details (local geological details, hydrogeological boundaries),

- the hydraulic relationship between surface waters and groundwaters,

- the role of the Lissos River in the aquifer salinization process,

- hydrochemical modeling combined with proper additional field tests (temperature and salinity logs in available wells) and hydrochemical types mapping

- groundwater flow modeling of the studied aquifer system.

The area of investigation is a typical example of lack of scientific groundwater resources management of coastal aquifers, which has resulted in the qualitative degradation of the aquifer and pose threats for a variety of factors of the area such as environmental, social, economic and agricultural development. 
Table 2 - Classifying groundwater samples of the study area based on relevant guidelines for interpretation of water quality for irrigation (Asano and Pettygrove 1987, Roscoe Moss Company 1990)

\begin{tabular}{|c|c|c|c|c|c|c|c|c|}
\hline & \multicolumn{8}{|c|}{ Potential Irrigation Problem expressed as Degree of Restriction on use } \\
\hline & \multicolumn{2}{|c|}{ salinity } & permeability & \multicolumn{5}{|c|}{ specific ion toxicity } \\
\hline & \multirow{2}{*}{$\begin{array}{l}\text { based on } \\
\text { EC } \\
(\mu S / \mathrm{cm}) \\
\text { values }\end{array}$} & \multirow{2}{*}{$\begin{array}{l}\text { based on } \\
\text { TDS } \\
\text { (mg/L) } \\
\text { values }\end{array}$} & \multirow{2}{*}{$\begin{array}{c}\text { based on } \\
\text { SAR \& } \\
\text { EC (mg/L) } \\
\text { values }\end{array}$} & \multicolumn{2}{|c|}{$\begin{array}{l}\text { based on } \mathrm{Na}^{+} \text {values } \\
(\mathrm{mg} / \mathrm{L})\end{array}$} & \multicolumn{2}{|c|}{$\begin{array}{l}\text { based on } \mathrm{Cl} \\
\text { values }(\mathrm{mg} / \mathrm{L})\end{array}$} & \multirow{2}{*}{$\begin{array}{c}\begin{array}{c}\text { based or } \\
\mathrm{HCO}_{3}^{-} \\
\text {values } \\
\text { (mg/L) }\end{array} \\
\begin{array}{c}\text { sprinkler } \\
\text { irrigation }\end{array}\end{array}$} \\
\hline & & & & $\begin{array}{l}\text { surface } \\
\text { irrigation } \\
\text { (SAR) }\end{array}$ & $\begin{array}{l}\text { sprinkler } \\
\text { irrigation }\end{array}$ & $\begin{array}{l}\text { surface } \\
\text { irrigation }\end{array}$ & $\begin{array}{l}\text { sprinkler } \\
\text { irrigation }\end{array}$ & \\
\hline well & \multicolumn{8}{|c|}{$8-7-2003$} \\
\hline 3 & SM & SM & SM & $\mathrm{N}$ & SM & $\mathrm{N}$ & SM & SM \\
\hline 6 & SM & SM & SM & $\mathrm{N}$ & SM & $\mathrm{S}$ & SM & SM \\
\hline 8 & SM & SM & SM & $\mathrm{N}$ & $N$ & $\mathrm{~S}$ & SM & SM \\
\hline 10 & SM & SM & $\mathrm{N}$ & SM & SM & $\mathrm{S}$ & SM & SM \\
\hline 14 & SM & SM & SM & SM & SM & $S$ & SM & SM \\
\hline 22 & $S$ & $S$ & $\mathrm{~N}$ & SM & SM & $S$ & SM & SM \\
\hline 23 & $S$ & $S$ & $\mathrm{~N}$ & SM & SM & $S$ & SM & SM \\
\hline 24 & SM & SM & SM & SM & SM & $S$ & SM & SM \\
\hline \multirow[t]{2}{*}{26} & $S$ & $S$ & $\mathrm{~N}$ & SM & SM & $S$ & SM & SM \\
\hline & \multicolumn{8}{|c|}{$20-7-2006$} \\
\hline 2 & SM & SM & $\mathrm{N}$ & $\mathrm{N}$ & $\mathrm{N}$ & $\mathrm{N}$ & $\mathrm{N}$ & SM \\
\hline 8 & SM & SM & SM & SM & SM & $\mathrm{N}$ & $\mathrm{N}$ & SM \\
\hline 11 & SM & SM & $\mathrm{N}$ & $\mathrm{N}$ & $\mathrm{N}$ & $\mathrm{N}$ & SM & SM \\
\hline 15 & SM & SM & SM & $\mathrm{N}$ & $N$ & SM & SM & SM \\
\hline 16 & SM & SM & $N$ & $\mathrm{~N}$ & $N$ & SM & SM & SM \\
\hline 18 & $\mathrm{~S}$ & SM & $N$ & $\mathrm{~N}$ & SM & S & SM & SM \\
\hline 19 & SM & SM & SM & $\mathrm{N}$ & $\mathrm{SM}$ & $N$ & $\mathrm{~N}$ & SM \\
\hline 20 & SM & SM & $\mathrm{N}$ & $\mathrm{N}$ & $\mathrm{N}$ & SM & SM & SM \\
\hline 25 & $S$ & $S$ & $\mathrm{~N}$ & $\mathrm{~S}$ & SM & $S$ & SM & SM \\
\hline
\end{tabular}

$\mathrm{N}$ : none, SM: slight to moderate, S: severe

It is recommended that the environmental problem of seawater intrusion regime of the area should be assessed by the local authorities (relevant municipalities or prefecture) in the form of managerial reports which could include the following:

- study of providing freshwater sources and design of proper groundwater artificial recharge facilities with continuous evaluation of their effectiveness,

- development of appropriate pumping scheme based on scientific evidence for the preservation of the entire piezometric surface of the area of investigation above sea level and organization of a series of educational seminars to the farmers of the area, in order to obtain appropriate knowledge for the pumping schemes which they should apply,

- construction of canals which will provide the migration of saline water towards preferred and certain parts of the study area,

- provision of specific measures for the problem of abandoned groundwater wells which may provide pathways for migration of saline water through different aquifer layers,

- thorough examination of the environmental impact assessment of each groundwater well which is about to be installed and inspection of the well drillers of the area and examination or evaluation of their scientific skills, 
- development of a water authority, as demanded by Directive 2000/60/EC, to ensure the protection of the quality status of the groundwaters of the area.

\section{References}

Asano, T., and Pettygrove, G. S., 1987. Using reclaimed municipal wastewater for irrigation, California Agriculture (March - April).

ASCE, 1987. Ground Water Management. Third Edition, ASCE Manuals and Reports on Engineering Practice No 40, New York, 263pp.

Ayers, R., S., 1975. Quality of water for irrigation. Proceeding of the Irrigation and Drainage Division, Specialty Conference, ASCE, 13-15/8/1975, Logan, Utah, 24-56 pp.

Kallergis, G., 1986. Applied Hydrogeology. Volume B, published by TCG, Athens. (in Greek)

Kallergis, G., 2000. Applied - Environmental Hydrogeology. Volume B, published TCG, Athens, $345 p$. (in Greek)

Mouzaliotis, A., 2006. Study of groundwater salinization progress within Xilagani - Imeros plain region in Rhodope Prefecture. Master Thesis submitted to the Department of Civil Engineers of D.U.Th., for the fulfillment of Postgraduate Program: Hydraulic Engineering, Xanthi, Greece, 183pp.

Piper, A. M., 1944. A graphic procedure in the geochemical interpretation of water analyses, Trans. Amer. Geophys. Union, 25, 914-923 pp.

Pliakas, F., Diamantis, I., Petalas, C., and Panilas, S., 2001. Feasibility study of artificial recharge application to Rhodope plain areas aquifers in Thrace, Greece. A first approach. Proceedings of the $9^{\text {th }}$ International Congress of the Geological Society of Greece, Athens, Greece, 26-28/9/2001, 5, 1923-1932. (in Greek)

Pliakas, F., Diamantis, I., Kallioras, A., and Petalas, C., 2004. Study of the progress of seawater intrusion within a plain area of Rhodope Prefecture. Proceedings of the $10^{\text {th }}$ International Congress of the Geological Society of Greece, Thessaloniki, Greece, 15-17/4/2004, $2057-$ 2066. (in Greek)

Roscoe Moss Company, 1990. Handbook of ground water development, Published by John Wiley \& Sons, USA, 493pp.

Sakkas, I., Diamantis, I., Pliakas, F., et al., 1998. Groundwater artificial recharge study of Xanthi Rhodope aquifers. Research Project for the Greek Ministry of Rural Development and Food. Sections of Hydraulics and Geotechnical Engineering, D.U.Th., Volume 3, Department of Civil Engineers D.U.Th., Xanthi. Greece. 